\title{
Testing market structure assumptions for DSGE modelling in Croatia using the SVAR model with long-run restrictions
}

\author{
Irena Palić ${ }^{1, \dagger}$, Ksenija Dumičić ${ }^{1}$ and Dajana Barbić ${ }^{1}$ \\ ${ }^{1}$ Department of Statistics, Faculty of Economics and Business, University of Zagreb \\ Trg J.F. Kennedy 6, HR-10000 Zagreb, Croatia \\ E-mail: 〈\{ipalic, kdumicic, dbarbic \}@efzg.hr 〉
}

\begin{abstract}
Assumptions on market structure are crucial in formulating dynamic stochastic general equilibrium (DSGE) models. The inclusion of the price stickiness assumption in DSGE models has questioned the money neutrality, which is a characteristic of DSGE models with perfect competition, and has thus opened the space for monetary policy analysis. One of the criteria used to determine which DSGE models are better suited to the characteristics of an observed empirical economy is the impact of technology shocks in the structural vector autoregression (SVAR) model with long-run restrictions. In DSGE models, assuming perfect competition with no price rigidity, i.e. real business cycle (RBC) models, changes in productivity that are driven by productivity shocks increase employment. On the other hand, new Keynesian (NK) models that assume imperfect competition and price rigidities, suggest that technological shocks decrease employment, since companies cannot adjust to excess production by reducing prices. In order to assess the impact of productivity shocks, the SVAR model with long-run restrictions is estimated using data on labour productivity, working hours and consumption in Croatia. The estimated impact of labour productivity shocks on working hours is statistically significant and negative, whereas the estimated impact on consumption is statistically significant and positive. The conducted analysis points to the fact that the DSGE model with imperfect competition and price rigidities describes the empirical characteristics of the Croatian economy better than the model with perfect competition.
\end{abstract}

Keywords: DSGE model, Long-run restrictions, Market structure, Price rigidities, SVAR model

Received: August 26, 2016; accepted: February 6, 2017; available online: March 31, 2017

DOI: 10.17535 /crorr.2017.0002

\section{Introduction}

Dynamic stochastic general equilibrium (DSGE) models have led to the integration of macroeconomics and microeconomics, providing a microeconomic basis for macroeconomic analysis. This approach provides a general framework for

$\dagger$ Corresponding author 
analysing the economic policy and its implications, which has been widely used in recent economic research. Research on the impact of macroeconomic shocks using DSGE models is the basis of modern macroeconomic research [23].

DSGE models are developed in the general equilibrium framework, where agents maximize their goals subject to defined constraints. Although real business cycle models (RBC) and new Keynesian (NK) models both have microeconomic foundations, the major difference is the type of market structure assumed in the model. While the RBC model assumes perfect competition, the assumption of NK models is imperfect or monopolistic competition. The RBC model assumes perfect competition and fully flexible prices, and the monetary policy has no effect on real variables in the economy. However, monetary policy has an effect on real variables in DSGE models assuming imperfect competition and price rigidities. With rigid prices, companies can gradually adjust prices over time, which creates real implications for the monetary policy [17]. In their paper [9] analyse monopolistic competition and optimal product variety, and present monopolistic competition using an aggregator of household preferences, which is incorporated in almost all DSGE models with the assumption of an imperfect market. According to [4], the inclusion of imperfect competition has led to substantial progress in compliance of DSGE models with real data, which is an important factor in the success of these models.

In DSGE models assuming perfect competition, changes in productivity driven by productivity shocks increase the working hours. On the other hand, NK models with the assumption of imperfect competition and price rigidities suggest that technological shocks decrease employment, given that companies cannot adjust to excess production by reducing prices $[7,16]$. The SVAR model is often used in literature to test the compliance of DSGE models' assumptions with empirical characteristics of observed economies [14, 15, 16, 23]. The research of [16] uses the SVAR approach to analyse the impact of technological shocks, whereat the response of working hours to technological shocks is considered the criteria according to which it is possible to determine which model is better suited to the characteristics of the observed empirical economy. The SVAR model with longrun restrictions is used in [16] in line with [5] and the research of [16] indicates that technological shocks are a source of negative correlation between production and working hours in the US. The research of [14], [15] and [16] indicates that due to a positive productivity shock in the US, output grows and working hours decrease. These results have challenged the compliance of RBC models with empirical features of the US economy.

The paper is structured as follows: after the introductory section, the market structure in DSGE models is briefly explained. Next, data used in the empirical analysis are described and the SVAR model with long-run restrictions is outlined. Then the empirical estimation of the SVAR model is conducted, and the main conclusions as well as a perspective for future research, are stated. 
Most attempts to detect the existence and importance of price stickiness rely on analysing microeconomic data, and data on the individual prices of goods and services [17, 23]. Regarding Croatia, the only research related to the empirical assessment of price competition was conducted by [24] in the form of a survey of companies and explored the extent to which prices are inflexible, as well as the causes of price rigidities. The mentioned research suggests that models of monopolistic competition are more appropriate for modelling the Croatian economy than models that assume perfect competition. On the macroeconomic level, the research of [2] offers a comprehensive analysis of the relationship between labour productivity and employment in transition countries including Croatia, and shows that productivity shock causes a decrease in employment measured by the number of employees. The research of [23] investigates the impact of market structure on the compliance of DSGE models with Croatian data. The question is posed as to whether the RBC model or the NK model better suits Croatian data, and subsequently the impact of productivity shocks on employment in Croatia is estimated. Besides the number of employees, in [23] working hours are also used to approximate employment in line with [16].

\section{The importance of market structure in DSGE modelling}

Adding imperfect competition and nominal rigidities to the basic RBC model has led to the development of NK models. The behavior of DSGE models and consequently the implications of these models for economic policy, largely stem from assumptions on determining market structure. Therefore, determining market structure and pricing behavior has been an important topic of empirical macroeconomics for many years [22].

In their research [3] and [18] have shown empirically that product markets are not perfectly competitive, and that companies add mark-up prices. These results have led to the development of models in which perfect competition is replaced by assuming monopolistic competition. Using this assumption, [20] has shown that the impact of productivity shocks in models with imperfect competition is weaker than in models with perfect competition, where other shocks gain a significant role in explaining economic fluctuations. The introduction of imperfect competition has had significant implications for macroeconomic modelling. With the assumption of imperfect competition, technological shocks have a lower impact on employment, and cyclical variations in employment must be caused by other shocks. An increase in productivity can therefore cause a fall in employment, since the wealth effect of the productivity shock on employment is stronger than in the model with perfect competition and is stronger than the substitution effect [26]. 
Perfect competition is assumed in RBC models. The addition of imperfect competition to macroeconomic models with microeconomic foundations was a challenge for Keynesian economists. Traditional Keynesian economics is based on the fact that prices are inflexible. The neoclassical revolution challenged Keynesian economists with the task of proving that price rigidity and market imperfections are justified in the general equilibrium model in which households maximize utility and companies maximise profits. New Keynesians are similar to Keynesians as they consider that imperfect competition and price stickiness are important features of an economy [23].

However, they differ from Keynesians in that they explore the macroeconomic framework with optimization decisions of rational economic agents assuming imperfect competition and price rigidity. One of the key issues is to understand price rigidity in terms of providing microeconomic fundamentals that would explain why prices are not perfectly flexible. To understand nominal rigidities, it was necessary to abandon the approach of perfect competition assuming pricetaking agents. To understand the price rigidity in the short run, it is necessary that economic agents determine prices in order to understand the microeconomic basis for price rigidity [10].

\section{Data and model description}

\subsection{Data}

VAR models used for evaluating DSGE models often include fewer variables than DSGE models [25]. The econometric practice is to use parsimonious models given that adding new variables reduces degrees of freedom, especially if taking into account that VAR models sometimes have a high number of lags. Therefore, some variables characteristic of DSGE models can be excluded from the VAR model in empirical analysis due to the preservation of degrees of freedom. In addition, some variables, such as capital, which are relevant in analysing DSGE models, are not easily estimated and there are different approaches to their estimation. Since output data are included in the calculation of labour productivity, the output time-series is not included separately in the SVAR model. Capital is not included as a separate variable as accumulation of capital depends on the investment which is included in the preliminary SVAR model. In their research [8] used the United States data and suggested that the inclusion of investment and consumption is important in minimizing the omitted-variable bias. Therefore, data on working hours, labour productivity, investment and consumption are initially used to estimate the SVAR model with long-run restrictions. Data selection for the SVAR model is in line with [8], [11] and [23]. 


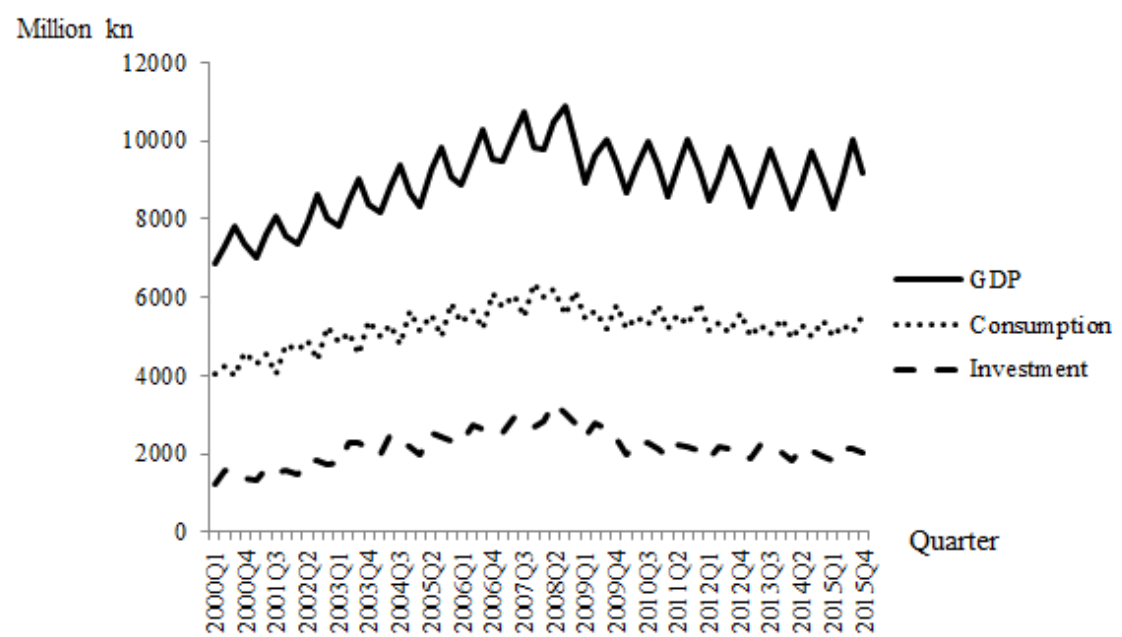

Figure 1: Real GDP, consumption and investment in Croatia from Q12000 to Q4 2015 [12]

Figure 1 shows the real GDP, consumption and investment data for Croatia from Q1 2000 to Q4 2015. Data on GDP and its components refer to quarterly data from $\lceil 12\rceil$ in 2005 based chain linked volumes. Investment is defined by gross fixed capital formation, while data on consumption refer to final consumption expenditure of households.

In evaluating DSGE models, employment is often approximated using working hours, and therefore this research uses working hours to approximate employment in Croatia. Data on working hours in Croatia are available after the first quarter 2000 [13], i.e. for the period from 2000 to 2008 data are available only for the first two quarters in each year. Therefore, in line with [23] data for the third and the fourth quarter in the missing period are estimated using the cubic spline interpolation method in the software MATLAB R2014a. 


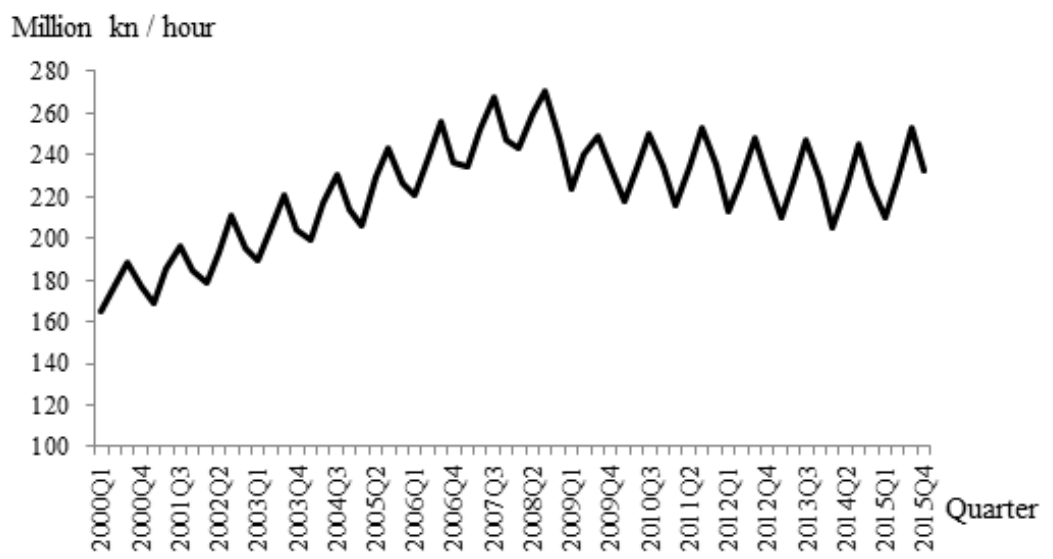

Figure 2: Labour productivity in Croatia from Q1/2000 to Q4/2015 [[13], and the estimation by authors for the third and the fourth quarter in the years from 2000 to 2008$]$

In this research, labour productivity is estimated as the ratio of real GDP and working hours in line with [17] and [19]. Since working hours for the third and the fourth quarter in the years from 2000 to 2008 are estimated using the cubic spline interpolation method, labour productivity is calculated using previously explained values of working hours for Croatia. Therefore, for the third and the fourth quarter for each year in the period from 2000 to 2008, labour productivity is calculated as the ratio between the real GDP and working hours which are interpolated using the cubic spline interpolation method. Figure 2 shows the calculated labour productivity in Croatia from the first quarter 2000 to the fourth quarter 2015.

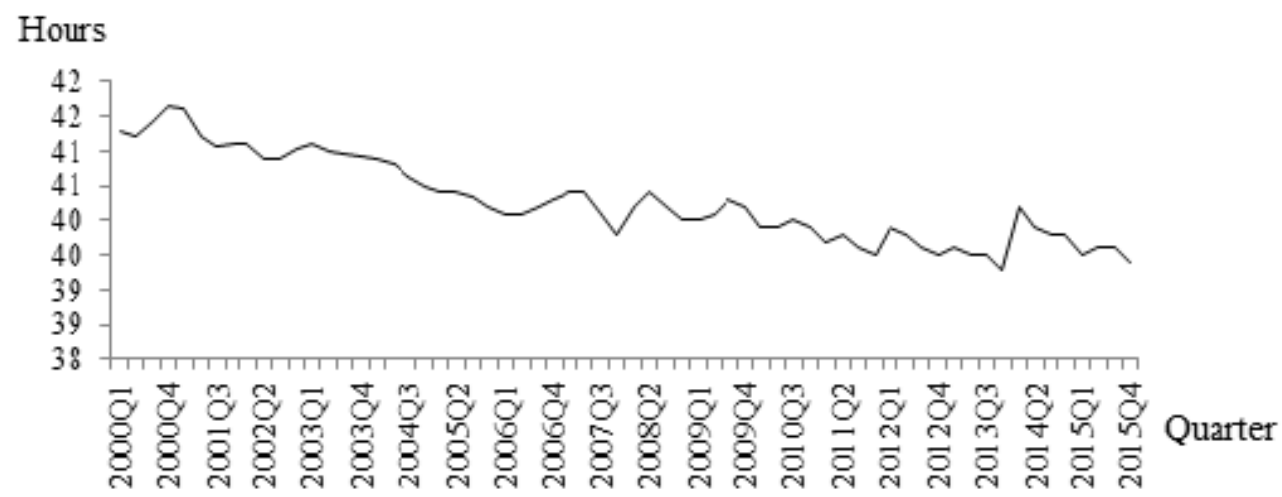

Figure 3: Working hours in Croatia from Q1 2000 to Q4 2015 [[13], estimation by the authors using the cubic spline interpolation method for the third and the fourth quarter in the years from 2000 to 2008] 
Graphical representations of the used data point to the fact that working hours shown in Figure 3 exhibit a decreasing trend of working hours in the observed period, while labour productivity, consumption and investment show an increasing trend. Prior to the SVAR model estimation, the logarithmic values of variables are seasonally adjusted using the X-13 ARIMA-SEATS quarterly seasonal adjustment method developed by [27]. The logarithmic value of labour productivity refers to the difference in logarithmic values of real GDP and working hours in line with [17], [19] and [23]. The stationarity of data is examined using the Augmented Dickey Fuller unit root test. Since all selected variables are nonstationary in levels, but stationary in first differences at $5 \%$ significance, the first differenced values of all variables are used in further analysis. In order to estimate the SVAR model with long-run restrictions, first differences of seasonally adjusted logarithmic values of all variables for the period from the first quarter 2000 to the fourth quarter 2015 are used, where $A$ refers to labour productivity, $H$ denotes working hours, $C$ denotes consumption and $I$ refers to investment.

\subsection{The SVAR model with long-run restrictions}

The structural vector autoregression (SVAR) model can be written as follows:

$$
A y_{t}=A_{1}^{*} y_{t-1}+\ldots+A_{p}^{*} y_{t-p}+B \varepsilon_{t}
$$

where $A_{j}^{*}=A A_{j}$ for $j=1, \ldots, p$.

Multiplying (1) with $A^{-1}$ leads to the reduced VAR model:

$$
y_{t}=A_{1} y_{t-1}+\ldots+A_{p} y_{t-p}+u_{t}
$$

where $A_{j}=A^{-1} A_{j}^{*}$ for $j=1, \ldots, p$ and $u_{t}=A^{-1} B \varepsilon_{t}$, which relates innovations of a reduced model with shocks of a structural model.

Identifying the parameters of the structural model requires imposing restrictions on matrices parameters (for detailed explanation see [1]). In the model, the longrun restrictions $\mathrm{B}$ vector of innovations $\varepsilon_{t}$ is modelled as a linear system such that $u_{t}=B \varepsilon_{t}$ and matrix $A=I_{k}$. In SVAR modelling, and it is common to analyse just-identified models. Therefore, there is the required number of restrictions necessary to achieve unique impulse response functions. In their research [5] focused on the total impact matrix given by (3):

$$
\sum_{i=0}^{\infty} \Theta_{i}=\left(I_{k}-, A_{1}-\ldots-A_{p}\right)^{-1} A^{-1} B
$$

and they identified structural innovations by putting zero restrictions on the total impact matrix. The assumption is that some shocks do not have long-run impacts. 
In the model with long-run restrictions, due to structural shocks from the residuals of the reduced model, matrix $A=I_{k}$ is defined and the restrictions on current impacts of observed variables are not imposed directly. The matrix of long run impacts:

$$
\left(I_{k}-A_{1}-\ldots-A_{p}\right)^{-1} B
$$

is a lower triangular matrix. Therefore, the second residual cannot have a longrun impact on the first variable; the third residual cannot have a long-run impact on the second and the third variable, and so on. Ensuring reliable restrictions requires adjusting the order of variables in the model. The estimation of the SVAR model with long-run restrictions is conducted using the Cholesky decomposition of the matrix (5):

$$
\left(I_{k}-\hat{A}_{1}-\ldots-\hat{A}_{p}\right)^{-1} \hat{\Sigma}_{u}\left(I_{k}-\hat{A}_{1}^{\prime}-\ldots-\hat{A}_{p}^{\prime}\right)^{-1}
$$

where ${ }^{-}$refers to the estimate from the reduced model $[21,23]$.

\section{The empirical estimation of the SVAR model}

Within the previously exposed SVAR model, the impulse response functions (IRFs) are estimated to expose the dynamic behavior of the system and present the response of the working hours, consumption and investment to a change in labour productivity for the next 20 quarters. Firstly, the SVAR model is estimated using the four above mentioned variables: labour productivity, working hours, consumption and investment. However, impulse response analysis has shown that the impact of labour productivity on investment is positive but statistically insignificant ${ }^{\ddagger}$. Therefore, to estimate final SVAR model, variable investment is excluded from the analysis and the final model is estimated using three variables: labour productivity, working hours and consumption. Estimates of the IRFs of the SVAR model with long run restrictions are shown in Figure 4.

\footnotetext{
* The results of the estimation of SVAR model which includes investment are available upon request.
} 

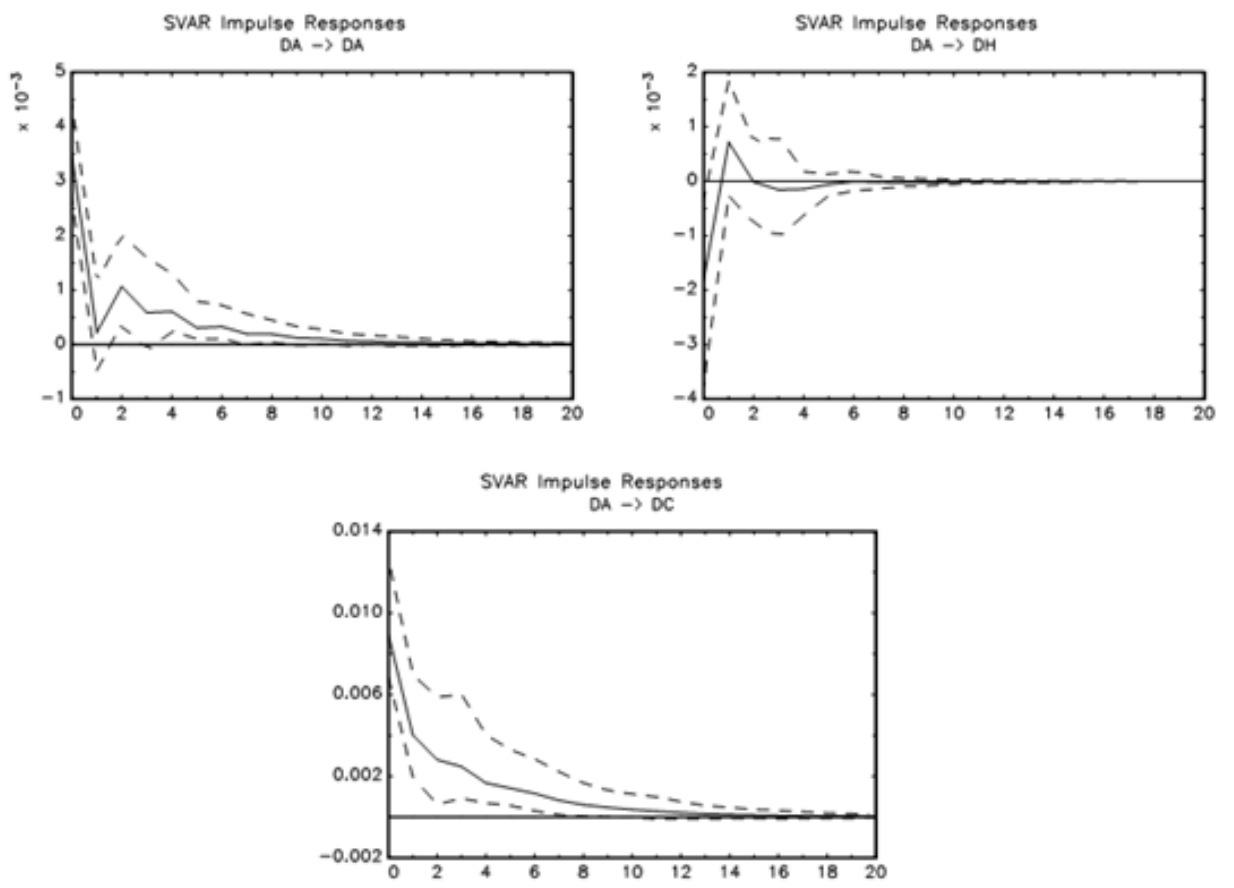

Figure 4: The impact of one standard deviation shock in the rate of change in labour productivity on rates of changes in labour productivity, working hours and consumption [Authors' calculation]

Figure 4 illustrates the effect of one standard deviation shock in the percentage change in labour productivity on percentage changes in labour productivity, working hours and consumption. In order to analyse the significance of IRFs, the 90\% Studentized Hall confidence intervals with 200 bootstrap replications are estimated using JMulTI software and interval bands are shown by dashed lines in the Figure 4. The Hall confidence interval estimates for the impulse response functions are explained in more detail in [6]. The initial effect of the shock in labour productivity on working hours is statistically significant and negative, and disappears after approximately 7 quarters. The effect on the consumption is initially positive and statistically significant. Considering the impact of labour productivity shock on the observed variables, the conclusion is that empirical impacts in the SVAR model with long-run restrictions are suited to DSGE models with imperfect competition, i.e. NK models. In NK models, the negative impact of productivity shocks on working hours can be explained by the inability of companies to reduce prices due to price inflexibility. Moreover, these results are contrary to DSGE models with a perfect competition assumption, where productivity shocks have a positive impact on working hours. 
Regarding the diagnostics of the model residuals, the White heteroskedasticity test is conducted. The White test chi-square test statistic equals 129.48, with the corresponding $p$-value of 0.0779 , which indicates that the null hypothesis of homoscedasticity cannot be rejected at the $1 \%$ significance level. For the residual autocorrelation test, the LM test is conducted. The null hypothesis of no autocorrelation of residuals cannot be rejected up to lag length $\mathrm{k}=12$ at the $10 \%$ significance level, since all corresponding empirical significance levels are greater than 0.10 . The stability of the model is checked by calculating the inverse roots of the characteristic AR polynomial using EViews8. The graphical representation of inverse roots is shown in Figure 5. Since no root lies outside the unit circle, the estimated model satisfies the stability condition.

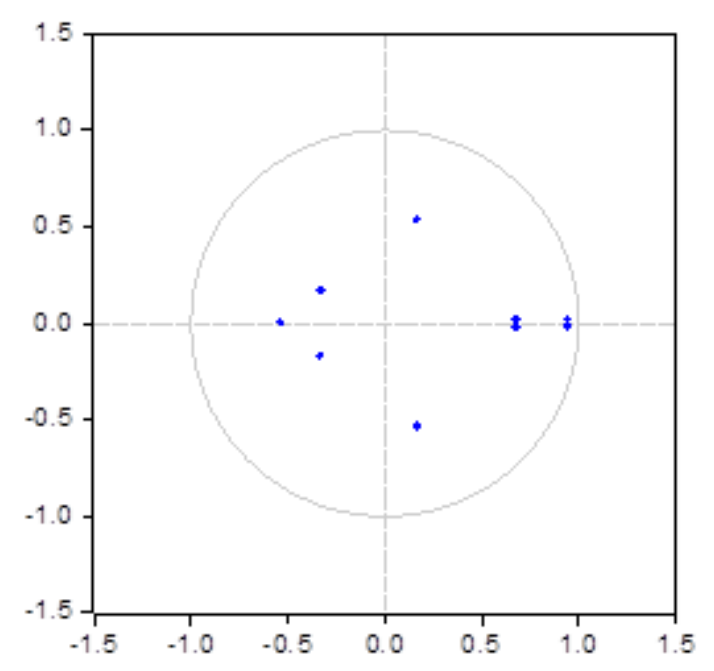

Figure 5: Inverse roots of AR characteristic polynomial [authors' calculation]

\section{Conclusions}

The analysis of conformity of DSGE models assumptions with the empirical characteristics of the observed economy has important implications for macroeconomic modelling as well as for the creation of economic policies. The question of modelling the market structure in DSGE models has been a widely investigated topic in macroeconomic analysis as it is related to the effectiveness of monetary policy. While in DSGE models which assume perfect competition and fully flexible prices, monetary policy has no effect on real variables in the economy, in DSGE models with an imperfect market and sticky prices, the monetary policy affects real variables. Therefore, the analysis of the market structure assumptions in DSGE modelling is important because of its implications for the economic policy-making process. 
Price determination in DSGE modelling can be related to macroeconomic variables through two aspects. Firstly, it can be linked through the effect of monetary policy on the real sector, as the imperfect pricing and price rigidities affect the non-neutrality of the monetary policy in the model with microeconomic foundations. Secondly, it can be related through the negative impact of a productivity shock on working hours because with inflexible prices, companies cannot adjust for the excess production by reducing prices. For monetary policy makers, finding about the importance of imperfect competition and price rigidities in economic modelling is important because imperfect competition in DSGE models indicates that monetary policy can have real effects.

The estimation of SVAR with long-run restrictions points to a significant negative impact of labour productivity on working hours in Croatia, and a significant positive impact on consumption. The conducted econometric analysis suggests that, regarding the impact of a productivity shock on working hours, DSGE models which assume imperfect competition are more in line with the Croatian economy than models which assume perfect competition. However, in future research it is also necessary to examine the impact of monetary shocks and analyse the impact of monetary variables on the real economic sector. The perspective for future research is to use the vector autoregression approach for assessing other DSGE models' assumptions such as various monetary policy rules, the existence of a foreign sector and financial frictions in modelling the Croatian economy.

\section{Acknowledgement}

This work has been fully supported by the Croatian Science Foundation under the project STRENGTHS no. 9402.

\section{References}

[1] Amisano, G. and Giannini, C. (1997). Topics in structural VAR Econometrics, 2nd ed. Berlin: Springer-Verlag.

[2] Arčabić, V. (2014) Tehnološki šokovi i nominalne rigidnosti kao uzroci poslovnih ciklusa u posttranzicijskim zemljama Europske unije (Tehnological shocks and nominal rigidities as couses of business cycles in posttransitional EU countries), PhD thesis, Faculty of Economics and Business, University of Zagreb.

[3] Basu, S. and Fernald, J. G. (1997). Returns to scale in US production: estimates and implications. Journal of Political Economy, 105 (2), 249-283.

[4] Bénassy, J.P. (2008). Dynamic models with non-clearing markets. In Durlauf, S.N. and Blume, L.E. (Eds.). The New Palgrave Dictionary of Economics. Palgrave Macmillan. 
[5] Blanchard, O.J. and Quah, D. (1989). The dynamic effects of aggregate demand and supply disturbances. American Economic Review, 79(4), 655-673.

[6] Breitung, J., Brüggemann, R. and Lütkepohl, H. (2004). Structural vector autoregressive modelling and impulse responses. In Lütkepohl, H. and Krätzig M. (Eds.). Applied Time Series Econometrics. Cambridge University Press.

[7] Cantore, C., León-Ledesma, M.A., McAdam, P. and Willman, A. (2010). Shocking stuff: technology, hours, and factor substitution. European Central Bank. Working Paper No. 1192.

[8] Christiano, L.J. Eichenbaum, M. i Vigfusson, R. (2003). What happens after a technology shock. National Bureau of Economic Research, Working Paper No. 9819.

[9] Dixit, A.K. and Stiglitz, J.E. (1977). Monopolistic competition and optimum product diversity. The American Economic Review, 67 (3), 297-308.

[10] Dixon, H.D. (2008) New Keynesian macroeconomics. In Durlauf, S.N. i Blume, L.E. (Eds.). The New Palgrave Dictionary of Economics. Palgrave Macmillan

[11] Erceg, C. J., Guerrieri, L and Gust, C. (2005). Can long-run restrictions identify technology shocks. Journal of the European Economic Association, 3 (6), $1237-1278$.

[12] Eurostat National Accounts: Quarterly accounts, GDP and main componentsvolumes. Available at: http://appsso.eurostat.ec.europa.eu/nui/show.do?data set $=$ namq_gdp_k\&lang $=$ en $[$ Accessed 01/07/2016]

[13] Eurostat Labour Force Survey, Average number of weekly hours of work. Available at: http://appsso.eurostat.ec.europa.eu/nui/show.do?dataset=lfsq ewhun2\&lang=en [Accessed 29/06/2016]

[14] Francis, N. and Ramey, V.A. (2005). Is the technology-driven real business cycle hypothesis dead? Shocks and aggregate fluctuations revisited. Journal of Monetary Economics, 52 (8), 1979-1399.

[15] Galì J. and Rabanal P. (2005). Technology shocks and aggregate fluctuations: How well does the RBC model fit postwar U.S. Data? International Monetary Fund. Working Paper No. 04/234.

[16] Galì, J. (1999). Technology, employment, and the business cycle: do technology shocks explain aggregate fluctuations? American Economic Review, 89 (1), 249-271.

[17] Galì, J. (2008). Monetary policy, inflation and business cycle: An introduction to the new keynesian framework. Princeton University Press.

[18] Hall, R. E. (1986). Market structure and macroeconomic fluctuations. Brookings Papers on Economic Activity, 2, 285-322.

[19] Hansen, G. D. (1985). Indivisible labor and the business cycle. Journal of Monetary Economics, 16 (3), 309-327. 
[20] Hornstein, A. (1993). Monopolistic competition, increasing returns to scale and the importance of productivity changes. Journal of Monetary Economics, 31 (3), 299-316.

[21] Lütkepohl, H., Krätzig, M. and Boreiko, D. (2006). VAR analysis in JMulTi. Available at: http://www.jmulti.de/download/help/var.pdf [Accessed 12/05 /16]

[22] Nakamura, E. and Steinsson, J. (2013). Price rigidity: microeconomic evidence and macroeconomic implications. National Bureau of Economic Research. Working Paper No. 18705.

[23] Palić, I. (2015). Econometric analysis and calibration of dynamic stohastic general equilibrium models of Croatian economy, PhD thesis, Faculty of Economics and Business, University of Zagreb.

[24] Pufnik, A. and Kunovac, D. (2013). Pricing behaviour of croatian compa-nies: Results of a firm survey and a comparison with the Eurozone. Croatian National Bank. Working paper No. W-236

[25] Ravenna, F. (2007). Vector autoregressions and reduced form representations of DSGE models. Journal of Monetary Economics, 54 (7), 2048-2064.

[26] Stadler, G.W. (1994). Real business cycles. Journal of Economic Literature, 32 (4), 1750-1783.

[27] U.S. Census Bureau (2013). X-13 ARIMA-SEATS Reference manual. Available at: http://www.census.gov/ts/x13as/docX13ASHTML.pdf [Accessed $13 / 03 / 16]$ 